University of Nebraska - Lincoln

DigitalCommons@University of Nebraska - Lincoln

June 2005

\title{
Combining Equity and the Precautionary Principle: Examples Drawn from Hog Production in Poland
}

F. Gregory Hayden

University of Nebraska - Lincoln, ghayden1@unl.edu

Follow this and additional works at: https://digitalcommons.unl.edu/cbafacpub

Part of the Business Commons

Hayden, F. Gregory, "Combining Equity and the Precautionary Principle: Examples Drawn from Hog Production in Poland" (2005). College of Business Faculty Publications. 13.

https://digitalcommons.unl.edu/cbafacpub/13

This Article is brought to you for free and open access by the Business, College of at DigitalCommons@University of Nebraska - Lincoln. It has been accepted for inclusion in College of Business Faculty Publications by an authorized administrator of DigitalCommons@University of Nebraska - Lincoln. 


\section{Combining Equity and the Precautionary Principle: Examples Drawn from Hog Production in Poland}

\section{F. Gregory Hayden}

Equity criteria are one set of efficiency criteria crucial for evaluating and judging production institutions and processes. Efficiency means the ability to produce a desired effect. Before efficiency can be determined, criteria must be established with regard to what is desirable. Equity-that is, fairness and justice - is one of the effects desired from production processes. ${ }^{1}$ Thus, (1) by definition, equity and efficiency cannot be separated. (2) Neither can they be separated in real-world production processes. If, for example, the loss of workers' respiratory health due to work in a hog production facility is considered unfair and unjust treatment of workers, the technological process is inefficient. (3) Nor can the two be separated for modeling and evaluation and be consistent with instrumentalism, which emphasizes that means and ends should not be separated in analysis because means and ends are a continuum. Likewise, to separate process from result and attempt to judge either one as the exclusive equity concern is an instrumental mistake. Consequently, attempts to separate equity from efficiency are not supported by definition, reality, or instrumental methodology. ${ }^{2}$

The purpose here is to use the author's methodological advice regarding the modeling of criteria, rules, regulations, and requirements (Hayden 1998) and to build on Steven Bolduc's application of that methodology (2004) in order to explain how to approach policy regarding equity issues. "Policy design and assessment should be guided by the recognition of social, ecological, and technological interdependence and by the discovery of evaluative criteria consistent with this interdependence" (Bolduc 2004, 181). There is no global set of equity criteria or global metric for a particular criteria set. The criteria set and metric depend on the problem chosen to study and the institutional

The author is Professor of Economics, University of Nebraska-Lincoln, USA. This paper was presented at the annual meeting of the Association for Evolutionary Economics in Philadelphia January 7-9, 2005. 
situation studied. Experience drawn from hog production in Poland is utilized here to demonstrate real-world situations and decisions regarding equity concerns.

Poland has recently experienced the entry of large hog-producing corporations from higher-income countries; these corporations have rapidly established large confinement facilities for swine. Smithfield Foods, Inc., the largest hog producer (with about one-third of total hog production in the United States) and largest pork processor in the United States, has been the most notable and powerful of these corporations and is responsible for establishing processes that exemplify inequity and lack of precaution. ${ }^{3}$ Media reports explain that the odor emanating from Smithfield hog facilities in Poland is horrible. At one facility, the Washington Post Weekly reported: "What it smells like is manure, with the most odor coming from a steaming mountain of pig waste and straw located at the edge of the property in an empty, frost covered field" (February 9-15, 2004). Such pollution treatment is inconsistent with socially accepted normative criteria. The migration of hog production to Poland is, in part, a case of environmental inequity, which is defined as the disproportionate location of dirty industries and waste sites for hazardous and toxic waste in low-income communities, thereby delivering elevated health risks to those with less income.

\section{Normative Criteria Combined for Equity}

Three sets of normative social criteria, to include equity criteria, are involved in the functioning of institutions. They are belief $\left(\mathrm{N}_{\mathrm{B}}\right)$, ecological $\left(\mathrm{N}_{\mathrm{E}}\right)$, and technological $\left(\mathrm{N}_{\mathrm{T}}\right)$. These norms are the standards for judging whether institutional patterns are appropriate. Belief norms are criteria that are enforced by the social process. Normalized beliefs are the societal criteria used to determine what institutional activity is acceptable and unacceptable. Ecological norms result from institutions delivering to and receiving from the ecological system. The interconnection between the two requires that ecological criteria be established and that rules, regulations, and requirements be established for institutional operations consistent with $\mathrm{N}_{\mathrm{E}}$. For example, when hogs and grain were taken from the ecological system, they were accompanied by an array of genetic characteristics which must be recognized in criteria for judging and guiding hog production processes. Since hogs are not cud-chewing animals, they have difficulty digesting phosphorous from the grains. Due to the combination of hogs and grain, hog manure is high in phosphorus, which, in turn, leads to a buildup of algae when the manure reaches rivers, streams, or lakes, thereby depleting the water of oxygen and killing fish. Ecological criteria that allow such fish kills are considered unfair and unjust treatment of those who depend on fishing for a livelihood. Technological norms that guide the selection of rules, regulations, and requirements for institutions are a result of institutional creation and implementation of technology. The literature of the social sciences about institutions has not recognized ecological and technological norms. Richard Scott's widely recognized book, Institutions and Organizations, which is a review of social science literature 
regarding norms and institutions, does not mention their existence (2001). The literature focuses on social beliefs, while the real world is dependent on all three normative sets.

In real-world operations, $\mathrm{N}_{\mathrm{B}}, \mathrm{N}_{\mathrm{E}}$, and $\mathrm{N}_{\mathrm{T}}$ are decided together and function together. They cannot function separately because all production includes belief commitments, ecological substance, pollution, and technological processes. The whole array of belief, ecological, and technological norms work together again and again, around the clock, both in the shadows and with full transparency, and in various kinds of institutional situations in order to determine the structure and processes of institutions. ${ }^{4}$ Likewise, it is crucial for welfare and equity determination to include the evaluation of all three together.

Each major norm has a number of subnorms $\left(\mathrm{n}_{\mathrm{B}}, \mathrm{n}_{\mathrm{T}}\right.$, and $\left.\mathrm{n}_{\mathrm{E}}\right)$ that apply to particular institutional situations. Major norms obligate subcriteria, as-

$$
\begin{aligned}
& \mathrm{N}_{\mathrm{B}} \supset \mathrm{O}\left(\mathrm{n}_{\mathrm{B} 1} \& \mathrm{n}_{\mathrm{B} 2} \& \mathrm{n}_{\mathrm{B} 3}\right) / \mathrm{I} \\
& \mathrm{N}_{\mathrm{T}} \supset \mathrm{O}\left(\mathrm{n}_{\mathrm{T} 1} \& \mathrm{n}_{\mathrm{T} 2}\right) / \mathrm{I} \\
& \mathrm{N}_{\mathrm{E}} \supset \mathrm{O}\left(\mathrm{n}_{\mathrm{E} 1} \& \mathrm{n}_{\mathrm{E} 2}\right) / \mathrm{I}
\end{aligned}
$$

The first row informs that $\mathrm{N}_{\mathrm{B}}$ directs $(\supset)$ an obligation $(O)$ of subcriteria $n_{B 1} \& n_{B 2} \& n_{B}$ to be adopted by institution $\mathrm{I}$, where the conjunction $(\&)$ means that the subcriteria are to be applied together. The second and third rows similarly inform $\mathrm{N}_{T}$ and $\mathrm{N}_{\mathrm{E}}$ for the same institution. This is demonstrated in digraph format in figure 1 . Therefore, all subcriteria are applied together as $\left(\mathrm{n}_{\mathrm{B} 1} \& \mathrm{n}_{\mathrm{B} 2} \& \mathrm{n}_{\mathrm{B} 3}\right) \&\left(\mathrm{n}_{\mathrm{T} 1} \& \mathrm{n}_{\mathrm{T} 2}\right) \&\left(\mathrm{n}_{\mathrm{E} 1} \& \mathrm{n}_{\mathrm{E} 2}\right)$. Scott 2001 also does not recognize this conjunction.

Figure 1. Norm Delivery of Conjunctive Subnorms

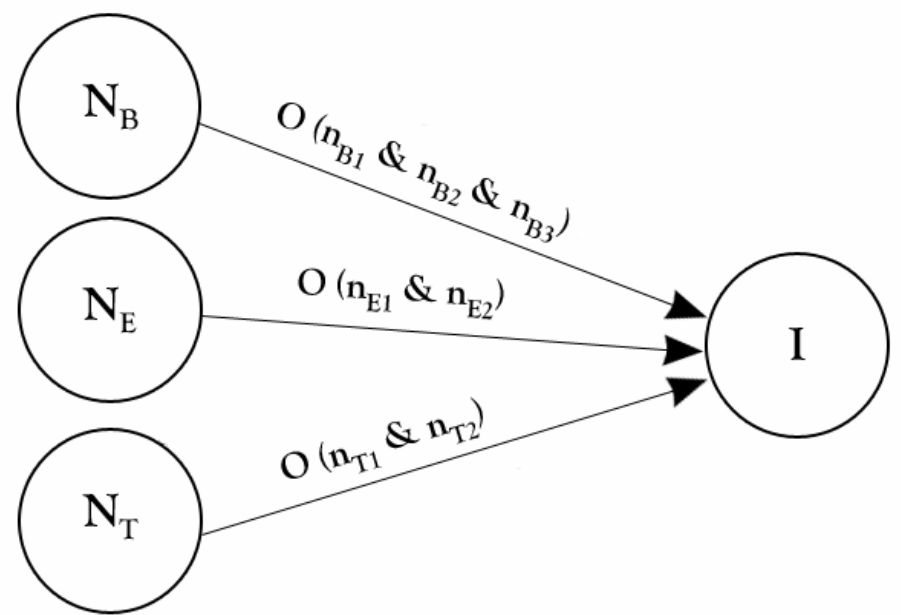


Although all three norms are represented in production situations, this does not mean the norms are correct. Because beliefs must be applied does not mean they are the belief norms of society in general. For example, the rules of the European Bank for Reconstruction and Development (EBRD) stipulate that producers like Smithfield should not receive funding, yet the norm actually instituted was to finance Smithfield, even though it adopted technological processes that damage ecological systems. ${ }^{5}$ Network analysis models need to specify what belief, technological, and ecological norms are actually guiding the industrial behavior and operations to allow judgments to be made about whether equity criteria are appropriately being established and met. Because $\mathrm{N}_{\mathrm{B}}, \mathrm{N}_{\mathrm{T}}$, and $\mathrm{N}_{\mathrm{E}}$ function together, when any one or all of them are not correct, the consequence is inefficiency. If this is the case for social-belief criteria about equity, there is equity inefficiency. Efficiency requires that a social consensus on normative criteria be utilized to judge the consequences of industrial procedures and operations. ${ }^{6}$ For example, at one of Smithfield's Polish hog facilities, in the spring of 2003 "when the ice melted, the manure-with a payload of nitrogen, phosphorus, artificial hormones, antibiotics and other waste products-seeped toward the nearby villages and lakes. The water turned brown, children got eye infections and skin rashes," and the smell was overwhelming (Washington Post Weekly, February 9-15, 2004). The eye and skin disease delivered to children is obviously unfair and unjust; thus the production process is inefficient. Furthermore, Smithfield generated an oversupply of hogs which drove down the price of hogs and financially destroyed thousands of local hog producers. This socially deviant behavior is an example of inequitable treatment of local farmers.

\section{Redefinition of Production Function Needed}

Recognizing and developing the relationship between equity and production would be enhanced if economics textbooks clarified that normative criteria are inherent in all real-world production functions. An extended discussion of related production function concepts is not possible here; however, it means a production function is not limited to inputs of capital, labor, ecological resources, and entrepreneurial ability. It is also dependent on normative criteria. Due to the inclusion of ecological concerns in economics, the utilization of the Cobb-Douglas production function that includes only capital and labor as inputs has been adversely criticized. ${ }^{7}$ The suggested alternatives, in turn, need to be replaced with production functions that include $\mathrm{N}_{\mathrm{B}}, \mathrm{N}_{\mathrm{E}}$, and $\mathrm{N}_{\mathrm{T}}$.

\section{The Precautionary Principle}

When social, technological, and ecological factors are combined to create an institutional organization, a whole set of criteria are applied to make judgments about the trajectory the process should follow. In the process of establishing normative criteria for the numerous situations of a production process, predictions are made about the conse- 
quences of various modes of operation. This is completed without full knowledge about consequences because it is a new process about which scientific analysis has not been completed. Since there is uncertainty about the expected pattern of any process to deliver desirable results and avoid undesirable ones in the future, precaution should be taken with regard to issues where uncertainty exists due to inadequate databases and adverse system dynamics that are ascertained. Reasonable persons who are attempting to deliver a set of process flows consistent with a set of criteria, therefore, take precautions. If reason and partial knowledge indicate the expectation that adverse effects might result from a process, precaution is appropriate. Taking such precaution is often referred to as the application of the precautionary principle. For processes to be equitable, planners need to take precautions with regard to fulfilling fairness and justice criteria (as well as with other criteria), thus making the precautionary principle relevant to equity concerns.

The precautionary principle was introduced into economic production discussions with regard to predictors of ecological consequences. This is necessary in order to obtain what Saeed Parto has referred to as an "environmentally superior technological transition" (2005). However, the principle is really not new. For centuries private legal contracts have had sections about what action will be taken or what in the contract is not binding if data are found to be of a particular character in the future. The same is true of international treaties. Experience with such contractual history may be the reason the precautionary principle has developed more rapidly in court proceedings and international treaties than in economic literature. ${ }^{8}$

The precautionary principle is part of a broader protectionist ethic (emphasized by Karl Polanyi) that calls for caution, which should be the case even when the full evidence about the degree of harm is uncertain. The principle emphasizes (1) that action should not be taken before there is sufficient scientific understanding of consequences from social or technical changes (such as the establishment of large confinement hog facilities) and (2) that changes should not be made prior to thorough analysis if there appears to be a basis to suspect damage from the social or technical change that is being contemplated, even if the adverse risk is uncertain.

The precautionary principle addresses anticipated threats, taking action to prevent the threats from occurring, with the lack of full scientific certainty not constituting a sufficient reason for postponing cost-effective measures to prevent harm (Cranor 1999, 76-77). The precautionary principle offers a strong presumption in favor of a high level of protection and a justification for treating certain functions or qualities as inviolable (Jordan and O'Riordan 1999, 27), suggesting that the burden of proof should shift to the production center or proto-developer to show no reasonable harm. In discussing the precautionary principle with regard to law, Andrew Jordan and Timothy O'Riordan stated: "Traditionally, the law has tended to privilege parties accused of degrading the environment rather than the victims of pollution" $(1999,28)$. The legal tendency with the precautionary principle is reversed. "The introduction of a strict liability regime ... would only require the victims to prove that the polluter failed to act with due diligence 
to gain compensation; in the case of absolute liability, the victim would merely need to prove that damage had occurred to gain financial restitution. More stringent still, would be to reverse the burden of proof entirely (i.e., the burden of proof is placed upon the proto-polluter to prove the emissions are 'harmless' before the activity is sanctioned) as in the licensing of new medicines" $(1999,28)$. Their statements also apply to criteria other than environmental-protection criteria. The precautionary concept will continue to evolve due to new research, changes in laws, and court decisions, and it will be more explicitly refined in its use to apply other criteria, especially equity criteria.

Research completed by Ken Geiser $(1999,325,327,334)$ regarding the precautionary concept is used to complete the five following points of advice regarding equity precaution: (1) The focus of attention for precaution should be on the point of production and design of the product rather than on how to deal with unwanted inequities. (2) Inquiry should be devoted to how the process or product can be modified to reduce or eliminate unwanted inequities. (3) The search is about discovering how much inequity is preventable rather than how much can be projected and tolerated. (4) Equity improvements are often possible through the substitution of technology. (5) "The precautionary concept needs to be developed as a practical decision-making tool for use by industrial managers in purchasing, process design, and work organization decisions" (Geiser 1999, 334).

Smithfield's aggressive expansion of hog production in Poland is a case in which precautionary concepts should have been employed to protect criteria of fairness and justice with regard to small hog producers. Scientific studies were not completed to predict the consequences of Smithfield's operation in Poland. However, there was sufficient evidence from vertical integration theory in economics and from Smithfield's history in the USA to surmise that Smithfield would bring excess supply to market to drive price below cost and unfairly destroy the small hog producers. The EBRD did not take precaution against that action. ${ }^{9}$ Instead, the EBRD funded Smithfield's activities when theory and historical record should have cautioned against funding the establishment of such an inequitable institutional situation. Policy makers should have acted prior to scientific certainty to protect equitable economic treatment of Polish farmers.

\section{Conclusion}

The whole production, financial, and marketing process needs to be considered and controlled in order to obtain equity. To wait and look only at the distribution of income and wealth after the process is operating is too narrow and too late-too narrow because many fairness and equity concerns exist beyond pecuniary distribution and too late because if the technology, market concentration, work conditions, wage structure, degree of vertical integration, environmental and social costs, and animal treatment are established the inequities are established. Precaution needs to be taken with the proto-developer. This is clear from the record of Smithfield's operations in Poland. 
Smithfield established its presence in Poland with the acquisition in 1999 of Animex, the former state-owned meat-trading company which became the largest meat-processing company in Poland after the demise of the Soviet empire, with major sales in Europe, United States, Russia, and Korea. Even with the establishment of numerous state farms under communism, about 80 percent of Polish farmland remained in private hands, as did most hog production. Now traditional hog producers are being destroyed and hog production transferred to large corporations. Animex/ Smithfield acquired various kinds of facilities and renovated them for hog production. When the renovations were completed, the die was cast for inequities. Family farms have been lost, communities damaged, and contract hog producers established who bear the excess costs. Manure is indiscriminately spread into communities and water systems, this being especially dangerous because of the germs, antibiotic residue, enzymes, nitrogen, preservatives found in feed supplements, and heavy metals. Animals and humans in the facilities are subjected to cruel and nonhumanitarian conditions because noise is maintained at high decibels and the air contains toxic gases. Polluted air from the hog factories contains about 160 volatile components, including hydrogen sulfide, ammonia, pathogenic bacteria, carbon monoxide and dioxide, organic dust, endotoxins, and methane. The Smithfield process is inefficient because of its inequities. Such inequitable cases can be prevented by turning attention to the establishment of acceptable $\mathrm{N}_{\mathrm{B}}, \mathrm{N}_{\mathrm{E}}$, and $\mathrm{N}_{\mathrm{T}}$ criteria on a precautionary basis for the selection of technology and establishment of production processes. Thus, concern for equity requires us to select acceptable equity norms to be utilized in establishing and guiding equitable institutional structures, technology, and production processes.

\section{Notes}

1. This statement does not mean to imply that equity concerns are limited to production or economic processes.

2. Traditionally, neoclassical economics has limited equity discussions to distributional effects that are narrowly defined as concerns about pecuniary distribution and has insisted on a conflict between equity and efficiency (e.g., see Anne Steineman et al. 2005, 139-156). More recently some neoclassical economists have pursued the issue of equity in a manner consistent with ultra-right-wing political philosophy in which "humanistic value" is defined as "consumer sovereignty" in the market and in which social decisions derived consistent with rules of the market are to be substituted for democratic voting (e.g., see Richard Tresch 2002, 8-13).

3. Smithfield Foods was among the most irresponsible corporations in 2000 according to the "Ten Worst Corporations of the Year" list released annually by Multinational Monitor (December 28, 2000).

4. This means, in terms of social fabric matrix (SFM) modeling, that because the three sets of norms are applied and implemented together, the SFM should contain entries in the receiving cells of institutional columns to indicate the deliveries of all normative sets.

5. The EBRD was established in 1990 for funding (1) private sector development of micro, small, and medium-sized enterprises and (2) smaller government-infrastructure investments 
from central Europe to central Asia-hardly criteria that fit Smithfield, the world's largest hog producer.

6. In terms of SFM modeling, the dominant societal norm and the deviant norm that is actually being delivered in the institution should both have their own row and column entries. The cell in an institutional column across from the dominant societal belief norm would be empty if it is completely ignored. Such an empty cell for belief norms devoted to equity would indicate inequity because belief norms are not being delivered to institutions consistent with what society considers desirable. The deviant belief imposed by an institution such as a corporation would be demonstrated by an entry in the SFM.

7. For discussion and review of relevant literature on production functions, see Ayres 1998 (203-206) and Baumgärtner 2000 (23-40 and 65-87).

8. Some cities in the United States have included statements of support for the precautionary principle, but they are neither specific to particular contexts nor utilized to guide particular actions.

9. A detailed report by Robert F. Kennedy, Jr., et al. about the locations and conditions surrounding Smithfield's hundreds of thousands of hogs in Poland can be found in the documentation submitted by Baiba Zasa of Latvia to the Helsinki Commission for a HELCOM HOD 11 meeting in Berhn to request the investigation of the situation by Smithfield (Kennedy 2003).

\section{References}

Ayres, Robert U. "Eco-thermodynamics: Economics and the Second Law." Ecological Economics 26 (August 1998): 189-209.

Baumgärtner, Stefan. Ambivalent Joint Production and the Natural Environment: An Economic and Thermodynamic Analysis. New York: Physica-Verlag, 2000.

Bolduc, Steven R. "Ceremonial Dimensions of Market-Based Pollution Control Instruments: The Clean Air Act and the Cap-and-Trade Model." Utilities Policy: Strategy Performance Regulation 12 (September 2004): 181-191.

Cranor, Carl F. "Asymmetric Information, The Precautionary Principle, and Burdens of Proof." In Protecting Public Health and the Environment: Implementing the Precautionary Principle, edited by Carolyn Raffensperger and Joel Tickner, 74-89. Washington, D.C.: Island Press, 1999.

Geiser, Ken. "Cleaner Production and the Precautionary Principle." In Protecting Public Health and the Environment: Implementing the Precautionary Principle, edited by Carolyn Raffensperger and Joel Tickner, 323-336. Washington, D.C.: Island Press, 1999.

Hayden, F. Gregory. "Normative Analysis of Instituted Processes." In Institutionalist Theory and Applications: Essays in Honour of Paul Dale Bush, vol. 2, edited by Sasan Fayazmanesh and Marc R. Tool, 89-107. Northhampton, Mass.: Edward Elgar, 1998.

Jordan, Andrew, and Timothy O'Riordan. "The Precautionary Principle in Contemporary Environmental Policy and Politics." In Protecting Public Health and the Environment: Implementing the Precautionary Principle, edited by Carolyn Raffensperger and Joel Tickner, 15-35. Washington, D.C.: Island Press, 1999.

Kennedy, Robert F., Jr., David Andrews, Ken Mitkiff, Tom Garret, and Julian Rose. Report on the situation created by operations of Smithfield Foods, Inc. in Poland. Submitted to Jean Lemierre, European Bank for Reconstruction and Development, London, United Kingdom, June 3, 2003. http://www.helcom.fi/ $\mathrm{dps} /$ docs/document/Heads.

Multinational Monitor, December 28, 2000.

Parto, Saeed. "Economic Activity and Institutions: Taking Stock." Journal of Economic Issues 39 (March 2005): 21-52.

Scott, W. Richard. Institutions and Organizations. London: Sage Publications, 2001.

Steinemann, Anne C., William C. Apgar, and H. James Brown. Microeconomics for Public Decisions. Mason, Ohio: Thomson Southwestern, 2005.

Tresch, Richard W. Public Finance: A Normative Theory, 2d ed. New York: Academic Press, 2002. 